\title{
Innovatív mikrobiológiai diagnosztikai gyorsteszt az antibiotikumrezisztencia terjedése ellen
}

\author{
Innovative rapid microbiological diagnostic test against the spread of antibiotic resistance \\ Farkas Szilvia1, Aszalós Zoltán Albert (MPhil, MBA, MSc)1, Dr. Prof. Szabó Dóra² \\ 'Semmelweis Egyetem Egészségügyi Menedzserképző Központ, \\ 2Semmelweis Egyetem Orvosi Mikrobiológiai Intézet
}

A cikkben egy új, innovatív gyorstesztet mutatunk be, mellyel közvetlenül a beteg mintájából ki lehet mutatni a legjelentősebb antibakteriális rezisztenciamechanizmusokat. A francia NG Biotech cég által kifejlesztett eszközt - az Európai Innovációs és Technológiai Intézet (European Institute of Innovation and Technology - EIT Health) által finanszírozott, és Magyarországon a Semmelweis Egyetem, illetve a Dél-Pesti Centrumkórház részvételével zajló - AMR DetecTool projekt keretei között vizsgáljuk és összehasonlítjuk a jelenleg használt standard módszerekkel.

This article presents a new, innovative rapid test that can detect the most significant antibacterial resistance mechanisms directly from a patient sample. Within the framework of the AMR DetecTool project funded by the EIT Health (European Institute of Innovation and Technology), the tool - developed by NG Biotech, a French innovative biotech company - will be tested and compared with the current standard testing methods.

\section{BEVEZETÉS}

A baktériumok antibiotikumokkal szembeni rezisztenciájának fokozódása világszerte népegészségügyi problémát és komoly kihívást jelent. Az Európai Betegségmegelőzési és Járványvédelmi Központ (European Centre for Disease
Prevention and Control, ECDC) évente közzéteszi a beérkezett jelentésekből készült riportjait az invazív izolátumok antimikrobiális rezisztenciájának alakulásáról [1], és interaktív térképen is bemutatja a rezisztens baktériumok előfordulás arányát [2]. A százalékban kifejezett értékek nagysága és ezeknek az értékeknek a folyamatos növekedése is aggasztó, lásd 1. ábra.

A multirezisztens baktériumok által okozott fertőzések kb. 33000 halálesetet okoztak Európában 2015. január 1. és 2015. december 31. között az EARS-Net adatok alapján [3], világszerte pedig kb. 700000 ember halálában játszhatnak vezető szerepet. Ha a jelenlegi tendencia folytatódik, 2050-re becslések szerint évente 10 millió ember fog meghalni a világban rezisztens baktériumok okozta fertőzések következtében [4].

Az antimikrobiális rezisztencia (AMR) ellen nemzetközi fellépés szükséges, ezért az Európai Bizottság 2017-ben elfogadta az „Egyesült Európai Egészségügyi Akciótervet az AMR ellen" (European One Health Action Plan against AMR), mely kimondja, hogy az újszerü, gyors és megbízható diagnosztika kulcsfontosságú a bakteriális és vírusos fertőzések elkülönítéséhez és az antimikrobiális rezisztencia azonosításához, hogy a legmegfelelőbb kezelést időben el lehessen kezdeni [5].

A jelenleg használatos rezisztencia meghatározási módszerek - a különböző szűrő és megerősítő tesztek: korongdiffúzió, E teszt, kettős korongdiffúzió, MALDI-TOF MS, Carba NP teszt - izolált baktériumokat igényelnek, ezért az
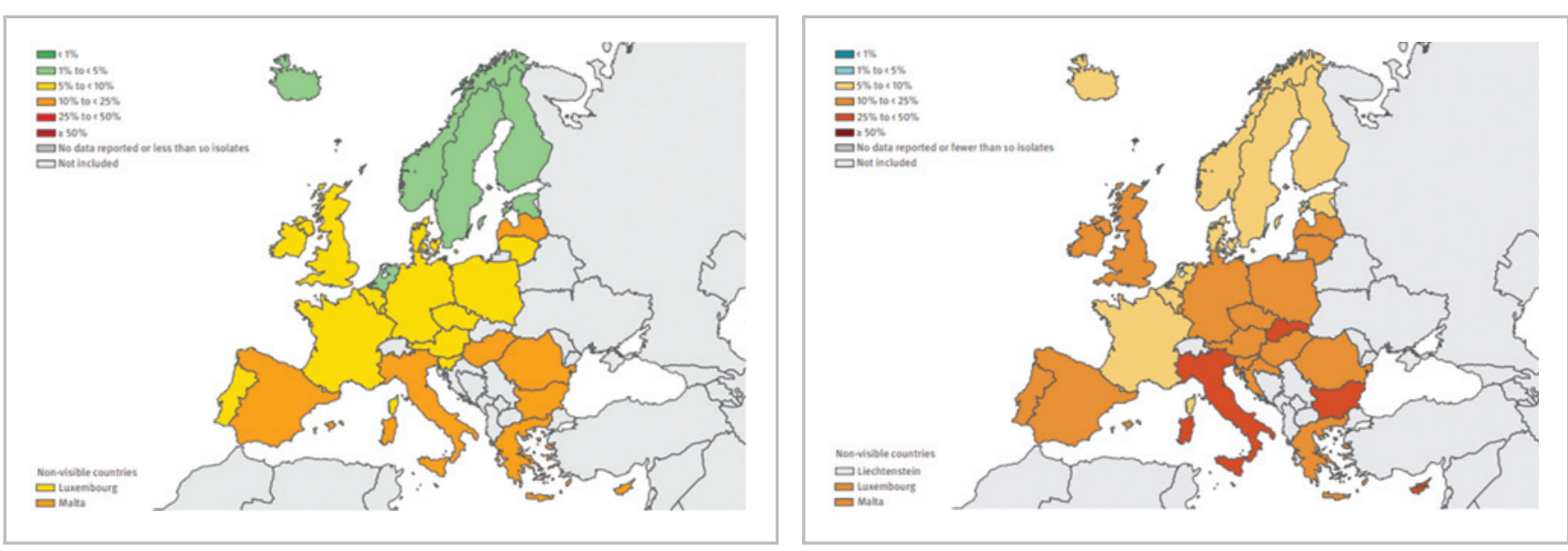

1. ábra

A 3. generációs cefalosporinokra rezisztens E. coli aránya Európa különböző országaiban 2009-ben és 2018-ben, Forrás: [1] 
eredmény elkészülése legalább 24 órát vesz igénybe. A PCR magas érzékenységű és specificitású, gyors diagnosztikai módszer, de drága, és speciális felszerelést és képzettséget igényel, nem érhető el minden kórházban.

\section{ÚJ DIAGNOSZTIKAI ESZKÖZ: AMR DETECTOOL}

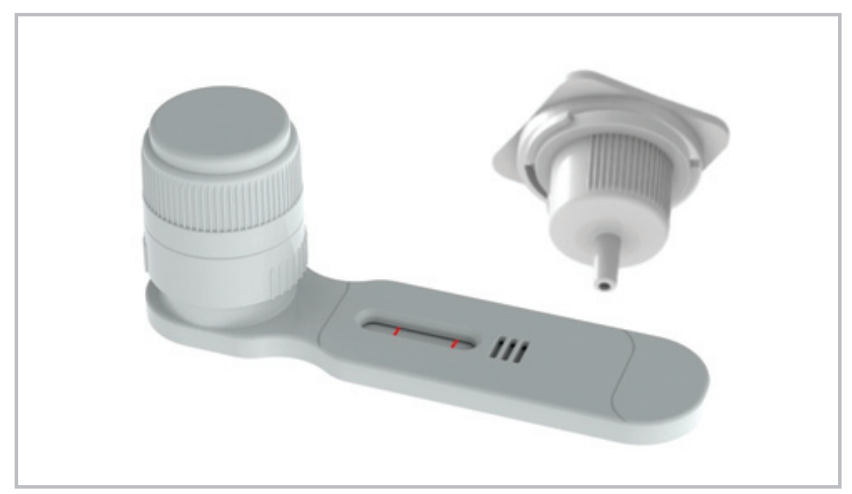

1. kép

Az NG Biotech által gyártott AMR DetecTool diagnosztikai eszköz

Az AMR DetecTool projekt keretében egy új gyorsdiagnosztikai eszközt tesztelünk, melynek segítségével a baktériumok kitenyésztése nélkül, közvetlenül a beteg mintájából ki lehet mutatni az alábbi rezisztenciamechanizmusokat: rezisztencia 3. generációs cefalosporinokkal szemben, a kiterjedt spektrumú béta-laktamáz (extended-spectrum betalactamase, ESBL) és karbapenemáz termelés az Enterobacteriales rendben, Vancomycin rezisztencia Enterococcus spp-ben, OXA-típusú karbapenemáz termelés Acinetobacter baumannii sp-ben. Az enzimek gyors kimutatása révén a beteg rövid időn belül - ideális esetben akár a minta levételét követő 30 perc múlva - megkaphatja a megfelelő antibiotikumot. Az eszköz használata könnyen elsajátítható és nincs szükség további speciális felszerelésre (lásd 1. kép).

\section{AZ ESZKÖZZEL KIMUTATHATÓ ANTIMIKROBIÁLIS REZISZTENCIÁK JELENTŐSÉGE}

Az eszközzel a járványügyi szempontból legjelentősebb és az egészségügyi intézményi környezetben leggyakoribb kórokozók rezisztenciamechanizmusait lehet kimutatni. A penicillinszármazékokat és a legtöbb cefalosporint hidrolizáló kiterjedt spektrumú béta-laktamáz (ESBL) termelés egyre gyakoribb az Enterobacteriales rendbe tartozó baktériumok között, melyek a kórházakban szerzett fertőzések közül föleg tüdőgyulladás, véráramfertőzés, húgyúti fertőzés, bőr- és lágyrészfertőzések okozói. Magas a kockázata az ESBL-termelő baktériumokkal való fertőzésnek a betegek hosszú kórházi tartózkodása, intenzív osztályos ellátása, invazív eszközök használata és széles spektrumú antibiotikumok előzetes adása esetén [6].

A karbapenemáz termeléséről egyre gyakrabban számolnak be a K. pneumoniae-ban, de más Gram-negatív kórokozókban, köztük a P. aeruginosa-ban is azonosították. A plaz- mid által közvetített karbapenem-rezisztenciával rendelkező K. pneumoniae jelentős kockázatot jelent a kórházban fekvő betegek számára. Ezeknek a rezisztenciaplazmidoknak az E. coli-ba történő átvitele jelentős közegészségügyi veszélyt jelent, mivel a rezisztens $\mathrm{E}$. coli a normál bélflóra részévé válhat, és ezáltal fertőzések forrása lehet az egészségügyi környezetben és a közösségben [7]. Az AMR DetecTool 5 különböző karbapenemáz típust mutat ki (OXA, KPC, NDM, IMP, VIM), és ezzel a terápia megválasztásához is útmutatást ad, ugyanis az OXA és KPC-termelő baktériumok által okozott fertőzések kezelhetők karbapenem és béta-laktamáz gátló kombinációjával [8, 9].

Az Enterococcusok nagy ellenállóképességgel rendelkeznek, hajlamosak kórházi környezetben hosszú időn keresztül fennmaradni, lehetővé téve a rezisztenciaelemek terjedését. Általában olyan immunszupprimált betegekben okoznak fertőzést, akik korábban antibiotikus kezelésben részesültek. Főleg húgyúti fertőzéseket, intraabdominális és kismedencei fertőzéseket, endokarditiszt, sebfertőzést okozhatnak. Fokozott a fertőzés veszélye dialízis kezelés, súlyos alapbetegség, immunszuppresszált állapot, invazív eszközök használata, hosszú kórházi ellátás, korábbi vagy jelenlegi antibiotikum terápia esetén. Az Enterococcusok vancomycin rezisztenciájáért nagyrészt a vanA gén felelős, és főleg az E. faecium hordozza [10]. A vanA gént hordozó Enterococcusok rezisztensek a vancomycinnel és a teicoplaninnal szemben, de a vanB hordozói érzékenyek lehetnek a teicoplaninra.

Az Acinetobacter baumannii világszerte jelentős kórokozónak számít a kórházban szerzett és az egészségügyi ellátással összefüggő fertőzésekben. A baktérium multirezisztenciáját elsősorban az OXA típusú karbapenemáz termelés okozza. A rezisztens törzsek főleg alsó légúti fertőzést (lélegeztetéssel összefüggő pneumóniát), véráramfertőzést, sebfertőzést, bőr- és lágyrészfertőzést okoznak. A baktérium a kórházi környezetben bárhol megtalálható, száraz felületeken hosszabb ideig fennmaradhat, gyakran elhúzódó járványokat okoz. A fertőzés kockázata magas intenzív osztályos ellátás esetén, égési sérüléseknél, traumatológiai betegeknél, lélegeztetett betegek, immunszuppresszált állapot és súlyos alapbetegség (krónikus tüdőbetegség vagy diabetes mellitus) esetén [11].

\section{AZ AMR DETECTOOL MŰKÖDÉSI ELVE}

Az AMR DetecTool diagnosztikai eszköz az LFIA (lateral flow immunoassay) elvén müködik, antigén-antitest reakció révén mutatja ki a baktériumok által termelt enzimeket közvetlenül a vizsgálati mintából: vizeletből, hemokultúrából, rektális törletből és légúti mintákból. A vizsgálati minta a kapillaritás elve alapján vándorol a tesztcsík mentén, és ha a mintában jelen vannak a kérdéses antigének (enzimek), kötődnek a tesztcsíkra felvitt specifikus antitestekhez. A teszt megfelelőségét beépített belső kontroll biztosítja.

Az eszköz elvégzi a minta szűrését, koncentrálását, egy speciálisan kialakított része az inkubációt is ellátja az ezt igénylő mintáknál. Nincs szükség további speciális felszere- 
lésre és a szűrés végrehajtása kis gyakorlással könnyen elsajátítható.

\section{A PROJEKT CÉLKITŰZÉSEI}

Az AMR DetecTool (amrdetect.eu) projektben megvizsgáljuk a módszer alkalmazhatóságát a standard módszerekhez képest: meghatározzuk a specificitást és a szenzitivitást, a pozitív és negatív prediktív értéket. Feltesszük a kérdést, hogy alkalmazható-e a jelenleg használt módszerek mellett a diagnózis felálításának meggyorsítására.

A laboratóriumi „spiked” mintákon kívül valódi betegmintákon is teszteljük az eszközt, a projekt céljai közé tartozik diagnosztikai algoritmus felálítása is, mely hozzájárulhat a betegek célzottabb szürését és kezelését elősegítő döntéshozatali stratégia kidolgozásához, ezáltal olyan betegutak kialakításához, mellyel költségmegtakarítást lehet elérni.

A projekt azt is hivatott bemutatni, hogy a kórházak, illetve az egészségügyi ellátórendszer milyen komoly mértékű költségmegtakarítást érhetnek el, ha a gyorsteszteket használva a beteg kezelésének kezdetén már eleve a hatásos antibiotikumot adják a páciensnek. A költségmegtakarítás abból adódik, hogy a gyorsan és célzottan nyújtott antibiotikumkúra hatására a páciensek kevesebb időt töltenek a kórházban, kevésbé fertőzik meg az egészségügyi dolgozókat, illetve más pácienseket, valamint eleve kevesebb antibiotikumra lesz szükség.

\section{A PROJEKT SZEREPLŐI}

A projekt az Európai Unió hivatalos szervezete, az Európai Innovációs és Technológiai Intézet (European Institute of Innovation and Technology - EIT Health) anyagi és szakmai támogatásával valósul meg. A projekt vezetője Hervé Volland, a Francia Alternatív Energiaforrások és Atomenergia Bizottság (CEA) munkatársa. A projektben résztvevő hazai intézmények: a Semmelweis Egyetemről az Egészségügyi Menedzserképző Központ, az Orvosi Mikrobiológiai Intézet és a Laboratóriumi Medicina Intézet, valamint a Dél-pesti Centrumkórház Mikrobiológiai Laboratóriuma.

A projekt során összegyűjtött szakmai információkról részletesen be fogunk számolni az amrexpert.eu weboldalon, a projekt tudásportálján, ezzel az egészségügyi szakembereknek szeretnénk hasznos ismeretekkel szolgálni. Az amrdetect.eu oldalon a projekt céljait, az egyes munkacsoportok aktualitásait mutatjuk be.

\section{IRODALOMJEGYZÉK}

[1] ECDC, Annual surveillance reports on antimicrobial resistance: https://www.ecdc.europa.eu/en/antimicrobial-resistance/surveillance-and-disease-data/report (megtekintve 2020. 11. 6-án)

[2] ECDC, Data from the ECDC Surveillance Atlas Antimicrobial resistance:

https://www.ecdc.europa.eu/en/antimicrobial-resistance/surveillance-and-disease-data/data-ecdc (megtekintve 2020. 11. 6-án)

[3] Cassini A, Högberg LD, Plachouras D, et al.: Burden of AMR Collaborative Group: Attributable deaths and disability-adjusted life-years caused by infections with antibiotic-resistant bacteria in the EU and the European Economic Area in 2015: a population-level modelling analysis, Lancet Inf. Dis. 2019 Jan; 19(1):56-66. https://doi.org/10.1016/S1473-3099(18)30605-4

[4] Review on Antimicrobial Resistance: https://amr-review.org/sites/default/files/160525_Final paper_with cover.pdf (megtekintve 2020. 11. 06-án)

[5] A European One Health Action Plan against Antimicrobial Resistance (AMR):

https://ec.europa.eu/health/sites/health/files/antimicrobial_resistance/docs/amr_2017_action-plan.pdf (megtekintve 2020. 11. 6-án)

[6] Rupp ME, Fey PD: Extended spectrum beta-lactamase (ESBL)-producing Enterobacteriaceae: considerations for diagnosis, prevention and drug treatment, Drugs. 2003; 63(4):353-65.

https://doi.org/10.2165/00003495-200363040-00002

[7] Goren MG, Carmeli Y, Schwaber MJ et al.: Transfer of Carbapenem-Resistant Plasmid from Klebsiella pneumoniae ST258 to Escherichia coli in Patient, Emerg Infect Dis. 2010 Jun; 16(6):1014-1017. https://doi.org/10.3201/eid1606.091671

[8] Stewart A, Harris P, Henderson A, Paterson D: Treatment of Infections by OXA-48-Producing Enterobacteriaceae, Antimicrob Agents Chemother. 2018 Nov; 62(11): e01195-18. https://doi.org/10.1128/AAC.01195-18

[9] Bhowmick T, Weinstein MP: Microbiology of MeropenemVaborbactam: A Novel Carbapenem Beta-Lactamase Inhibitor Combination for Carbapenem-Resistant Enterobacterales Infections, Infect Dis Ther. (2020). https://doi.org/10.1007/s40121-020-00350-1

[10] O’Driscoll T, Crank CW: Vancomycin-resistant enterococcal infections: epidemiology, clinical manifestations, and optimal management, Infect Drug Resist. 2015; 8: 217-230. https://doi.org/10.2147/IDR.S54125

[11] Viehman JA, Nguyen MH, Doi Y: Treatment Options for Carbapenem-Resistant and Extensively Drug-Resistant Acinetobacter baumannii Infections, Drugs. 2014 Aug; 74(12): 1315-1333. https://doi.org/10.1007/s40265-014-0267-8 


\section{A SZERZŐK BEMUTATÁSA}

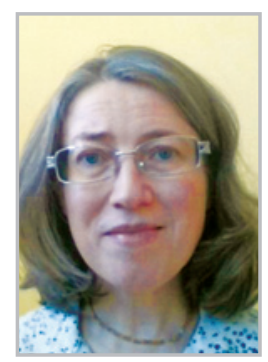

Farkas Szilvia biológus, MSc ökológus és posztgraduális mikrobiológus végzettséggel. 2017-ben csatlakozott a Semmelweis Egyetem Egészségügyi

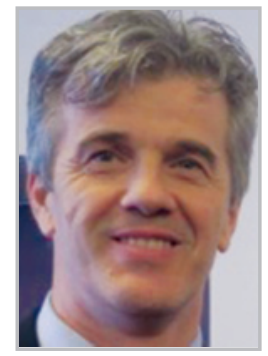

Aszalós Zoltán Albert MPhil, MBA, MSc a Semmelweis Egyetemen 2012 óta az Egészségügyi Menedzserképző Központ munkatársa. Nemzetközi projektekben munkacsoportokat vezet pro-

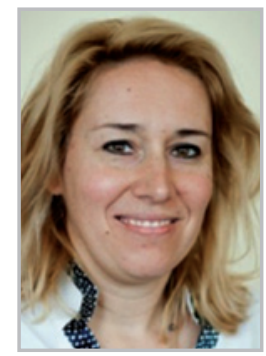

Prof. Dr. Szabó Dóra az MTA doktora, a Semmelweis Egyetem Általános Orvostudományi Kar Orvosi Mikrobiológiai Intézet igazgatója és egyetemi tanára.
Menedzserképző Központjához, ahol szakmai szakértőként vesz részt hazai és nemzetközi projektekben. Ezt megelőzően kórházi laboratóriumokban dolgozott mikrobiológusként és minőségirányítási auditorként.

jektmenedzserként. Az AMR DetecTool projektben a Tudásportál, valamint a Kommunikációs munkacsoportok vezetését látja el. Közgazdasági, jogi, MBA és adattudomány területen szerzett végzettséget.

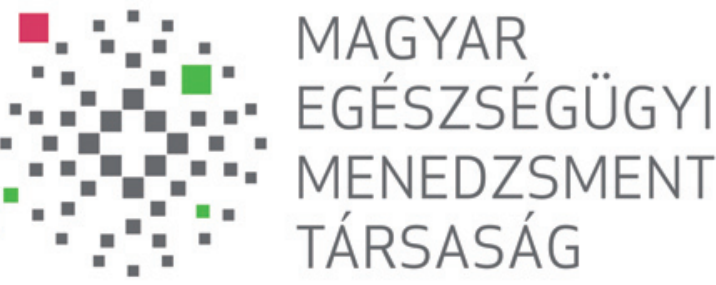

www.memt.hu

- SZAKMAI ESEMÉNYEK, KONFERENCIÁK, MÜHELYBESZÉLGETÉSEK, KÉPZÉSEK SZERVEZÉSE ÉS MEGVALÓSÍTÁSA

- DIGITÁLIS EGÉSZSÉGÜGYI TECHNOLÓGIÁK FEJLESZTÉSÉNEK TÁMOGATÁSA

- KUTATÁS - FEJLESZTÉSI TEVÉKENYSÉGEK TÁMOGATÁSA
- STRATÉGIAI TANÁCSADÁS

SZAKMAI KIADVÁNYOK KÉSZÍTÉSE

TARTALOMMENEDZSMENT

— HÍRLEVÉLSZOLGÁLTATÁSOK

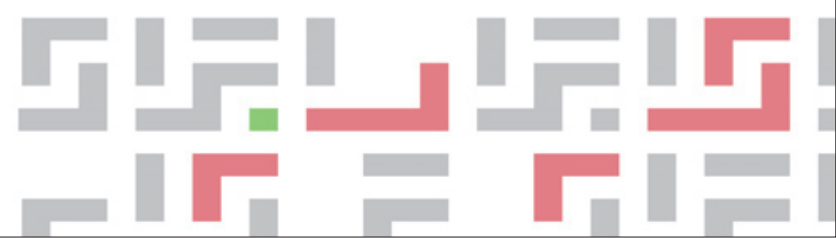

